\title{
PELATIHAN PENERAPAN PENILAIAN AUTENTIK PADA KELOMPOK KERJA GURU DI KECAMATAN MEKARSARI KABUPATEN BARITO KUALA
}

\author{
Barsihanor $^{1 *}$, Abdul Hafiz ${ }^{2}$, \\ ${ }^{1}$ Pendidikan Guru Madrasah Ibtidaiyah, Universitas Islam Kalimantan MAB Banjarmasin, \\ barsihanor90@gmail.com \\ ${ }^{2}$ Pendidikan Guru Madrasah Ibtidaiyah, Universitas Islam Kalimantan MAB Banjarmasin, \\ abdulhafiz_haji@yahoo.com
}

\begin{abstract}
ABSTRAK
Abstrak: Penilaian autentik diperlukan guru untuk mengetahui apakah siswa benarbenar belajar atau tidak, apakah pengalaman belajar siswa memiliki pengaruh yang positif terhadap perkembangan siswa, baik intelektual maupun mental siswa. Pada penilaian autentik siswa tidak hanya dinilai pengetahuannya saja, tetapi siswa juga dinilai keterampilan dan sikap siswa sehari-hari. Siswa yang pintar secara pengetahuan belum tentu memiliki keterampilan dan sikap yang baik di kehidupan sehari-hari, begitu juga sebaliknya. Oleh karena itu, penilaian autentik sangat penting diterapkan di SD agar siswa dapat dibimbing untuk tidak hanya memiliki kemampuan di bidang pengetahuan saja, tetapi juga sikap dan keterampilan. Kegiatan pengabdian ini bertujuan untuk meningkatkan kemampuan mahasiswa dalam mendesain penilaian dengan pendekatan autentik. Metode pelaksanaan kegiatan ini berupa pelatihan, Metode pelatihan dilakukan dalam dua bagian utama, yaitu pembuatan instrument tes dan cara melakukan penilaiannya serta terakhir dilakukan tanya jawab.

Kata Kunci: Penilaian, Autentik.

Abstract: Authentic assessment is required teachers to find out whether students really learn or not, whether the learning experience of students have a positive influence on students development, both intellectual and mental students. Authentic assessment on students not only assessed knowledge alone, but students are also assessed the skills and attitudes of students daily. Smart students are not necessarily have knowledge of skills and good manners in daily life, as well as vice versa. Therefore, authentic assessment is very important to applied in the elementary school so that students can be guided to not only have the ability in the field of knowledge, but also attitudes and skills. This devotion activities aims to improve students' ability in designing an assessment with an authentic approach. The method of implementation of these activities in the form of training, methods of training are conducted in two main parts, namely the making of instrument tests and how to do the assessment and the last done question and answer.

Keywords: Assessment, Authentic.
\end{abstract}

Riwayat Artikel: Diterima: 17-12-2017, Disetujui: 31-01-2018

\section{A. PENDAHULUAN}

Penilaian pendidikan merupakan proses pengumpulan dan pengolahan informasi untuk mengukur pencapaian hasil belajar peserta didik mencakup penilaian autentik, penilaian diri, portofolio, ulangan harian, ulangan semester dan ulangan akhir semester. (Dwi Doso Warso, 2014). Dengan dikembangkannya menjadi Kurikulum 2013 diharapkan mampu 
membekali siswa secara utuh baik dari aspek intelektual, emosional dan spiritual.

Dalam Kurikulum 2013, kegiatan pembelajaran dilaksanakan berdasarkan pada standar kompetensi lulusan, kompetensi inti dan kompetensi dasar. Standar Kompetensi Lulusan (SKL) yang telah dirumuskan untuk jenjang satuan pendidikan SD/MI digunakan untuk merumuskan kompetensi dasar yang diperlukan untuk mencapainya dan SKL harus dicapai pada akhir jenjang SD/MI yang lamanya 6 tahun. Untuk memudahkan operasional perumusan kompetensi dasar, diperlukan tujuan yang menyatakan capaian kompetensi pada tiap akhir jenjang kelas. Capaian kompetensi pada tiap akhir jenjang kelas dari kelas 1 sampai 6 disebut dengan kompetensi inti. (Prastowo, 2013)

Kompetensi inti dan kompetensi dasar adalah turunan dari standar kompetensi lulusan (SKL). Berkaitan dengan hal tersebut, kompetensi utama yang diharapkan dalam proses pembelajaran ini adalah kompetensi sikap, pengetahuan dan keterampilan. Untuk mengukur kompetensikompetensi tersebut membutuhkan waktu yang lama dimana harus berdasarkan penilaian proses dan hasil. Sistem penilaian yang cocok dengan melihat kompetensi-kompetensi yang diharapkan yaitu dengan penilaian autentik.

Udin Syaefudin Sa'ud menjelaskan bahwa penilaian autentik adalah proses yang dilakukan guru untuk mengumpulkan informasi tentang perkembangan belajar yang dilakukan siswa. (Sa'ud, 2013) Penilaian autentik merupakan penilaian yang sangat penting dan diperlukan oleh guru. M. Hosnan menjelaskan bahwa penilaian autentik diperlukan guru untuk mengetahui apakah siswa benar-benar belajar atau tidak, apakah pengalaman belajar siswa memiliki pengaruh yang positif terhadap perkembangan siswa, baik intelektual maupun mental siswa. (Hosnan, 2014).

Siswa tidak hanya dinilai pengetahuannya saja, tetapi siswa juga dinilai keterampilan dan sikap siswa sehari-hari. Siswa yang pintar secara pengetahuan belum tentu memiliki keterampilan dan sikap yang baik di kehidupan sehari-hari, begitu juga sebaliknya. Oleh karena itu, penilaian autentik sangat penting diterapkan di SD agar siswa dapat dibimbing untuk tidak hanya memiliki kemampuan di bidang pengetahuan saja, tetapi juga sikap dan keterampilan. Ketiga kompetensi tersebut nantinya akan sangat dibutuhkan siswa sebagai bekal di masa yang akan datang.

Pada kenyataan di lapangan masih banyak guru-guru yang belum memahami penilaian autentik dan mengaplikasikannya, termasuk guruguru Madrasah Ibtidaiyah di Kecamatan Mekarsari, padahal penilaian autentik bagian dari kurikulum 2013. Penilaian autentik mengharuskan guru untuk merancang instrumen terlebih dahulu dan dalam pengaplikasiannya dimulai dari proses pembelajaran hingga akhir, 
disamping itu dalam penilaian autentik guru juga dituntut untuk menguasai teknologi komputer, sedangkan kenyataanya dari ungkapan guru menerangkan kalau banyak guru-guru yang masih belum terlalu bisa mengoperasionalkan komputer.

\section{B. METODE PELAKSANAAN}

Metode pelaksanaan kegiatan ini berupa pelatihan, Metode pelatihan dilakukan dalam dua bagian utama, yaitu pembuatan instrument tes dan cara melakukan penilaiannya. adapun rangkaian kegiatan pelatihan tersebut antara lain:

1. Praktek

Diawali dengan demontarasi dan praktek tentang; 1) pembuatan instrumen tes kognitif, 2) pembuatan instrumen tes afektif, 3) pembuatan instrumen tes psikomotorik.

2. Cara melakukan penilaian

Setelah semua peserta membuat instrumen tes, akan didemontarsikan cara mengunakanya saat melakukan pembelajaran, setiap siswa diminta bergantian untuk mensimulasikan cara penilaian saat pembelajaran.

3. Tanya Jawab

Semua peserta pelatihan ini diberikan kesempatan untuk bertanya tentang sesuatu yang belum jelas, baik yang telah disampaikan dalam presentasi maupun hal-hal lain yang berkaitan dengan langkah-langkah penilaian autentik.

\section{HASIL DAN PEMBAHASAN}

Kegiatan Kelompok Kerja Guru Se-Kecamatan Mekarsari Kabupaten Barito Kuala ini diikuti 42 orang guru Madrasah Ibtidaiyah yang terdiri dari Kepala Sekolah dan Guru MI di Kecamatan Mekarsari Kabupaten Barito Kuala. Hasil kegiatan pelatihan Pelatihan Penilaian Autentik pada Kelompok Kerja Guru di Kecamatan Mekarsari Kabupaten Barito Kuala Kabupaten Barito Kuala terlaksana sesuai dengan rencana jadwal yang telah disusun dan hasil kegiatan tersebut dapat dijabarkan sebagai berikut:

Kegiatan ini diawali dengan penyampaian materi. Materi yang pertama disampaikan tentang substansi penilaian autentik yang mencakup tiga ranah, yakni pengetahuan, afektif dan keterampilan, kemudian dilanjutkan dengan pembuatan atau pengembangan instrumen penilaian. Setelah penyampaian materi pembuatan instrumen tes dilanjutkan dengan simulasi penilaian autentik dalam pembelajaran. Setelah simulasi.

Setelah penyampaian materi dan simulasi penilaian autentik, dilakukan tanya jawab. Adapun beberapa pertanyaan yang dilontarkan peserta saat kegiatan berlangsung adalah:

1. Supian (Guru MIS Nurul Iman) 
a. Apakah instrument tes pada ranah afektif boleh guru kembangkan?

b. Tidak jarang seorang guru kesulitan dalam mengelola kelas, bagaimana cara guru menerapkan penilaian afektif observasi dengan kondisi pembelajaran yang kurang kondisif?

2. Rusdiyah (Guru MIS Nurul Ihsan)

Bagaimana cara menyimpulkan penilaian akhir melalui penilian autentik ini?

3. Burhanudin, S. Pd. I (MIN Mekarsari)

a. Apakah penilaian observasi dilakukan pada saat pembelajaran saja?

b. Apakah ada tindak lanjut dari guru berdasarkan hasil penilaian afektif?

4. Khairani, S. Pd. I (MIS Darul Huda)

a. Murid-murid di kelas biasanya sering ribut dan suka jalan-jalan di kelas, bagaimana cara menerapkan penilaian autentik ini agar efektif?

b. Bagaimana cara mengolah hasil penilaian autentik tersebut ke dalam raport siswa?

Semua pertanyaan tersebut dapat dijelaskan dan langsung dipraktekkan dengan baik secara klasikal dan individu sehingga semua peserta merasa puas dengan pelatihaan yang telah diberikan. peserta pelatihan tampak aktif dan antusias untuk mengikuti kegiatan tersebut, kerena kami mencoba mengkombinasikan pembelajaran dengan game-game yang membuat suasana kegiatan menjadi lebih aktif.

Walaupun secara umum kegiatan pelatihan ini berjalan dengan lancar, namun ada beberapa yang kami dapati dilapangan di antarnya:

1. Kurangnya waktu dalam pelatihan ini yang salah satunya diakibatkan keterlambatan kegiatan di mulai sebagaimana waktu yang telah ditentukan sehingga kegiatan pelatihan penerapan penilaian autentik ini tidak bisa dilaksanakan secara tuntas, maka dari itu kami hanya utamakan menjelaskan tentang penilaian autentik ranah afektif saja.

2. Masih banyak guru-guru yang selama ini dalam melakukan penilaian hanya menggunakan penilaian pengetahuan jenis multiple coise dan essay, sehingga untuk memahami penilaian afektif mengalami kesulitan.

3. Sebagian besar guru terlihat masih malu-malu dalam mengikuti pelatihan dan simulasi penlaian, hal tersebut bisa berdampak pada sulitnya kami dalam menganalisis, apakah peserta pelatihan sudah memahami materi atau belum materi yang sudah disampaikan.

Minimnya bahan atau modul pelatihan yang kami bagikan mengakibatkan sebagian guru tidak mendapatkan. 


\section{SIMPULAN DAN SARAN}

Hasil kegiatan pelatihan Pelatihan Penilaian Autentik pada Kelompok Kerja Guru di Kecamatan Mekarsari Kabupaten Barito Kuala Kabupaten Barito Kuala terlaksana sesuai dengan rencana jadwal yang telah disusun. Kegiatan ini diawali dengan penyampaian materi. Materi yang pertama disampaikan tentang substansi penilaian autentik yang mencakup tiga ranah, yakni pengetahuan, afektif dan keterampilan, kemudian dilanjutkan dengan pembuatan atau pengembangan instrumen penilaian. Setelah penyampaian materi pembuatan instrumen tes dilanjutkan dengan simulasi penilaian autentik dalam pembelajaran. Setelah simulasi. Untuk peneliti selanjutnya penulis sarankan untuk menyiapkan perangkat atau instrumen tes lebih banyak dan membuat modul pelatihan terlebih dahulu.

\section{UCAPAN TERIMA KASIH}

Tim penulis mengucapkan terima kasih kepada Dekan Fakultas Studi Islam dan Lembaga Pengabdian Pada Masyarakat (LPPM) Universitas Islam Kalimantan Muhammad Arsyad Al-Banjari Banjarmasin yang telah mendanai kegiatan pengabdian ini sehingga terlaksana dengan baiks, serta kepada ketua KKG MI Kecamatan Mekarsari beserta guru-guru yang telah hadir pada kegiatan pelatihan tersebut.

\section{DAFTAR RUJUKAN}

[1] Dwi Doso Warso, A. W. Proses Pembelajaran dan Penilaiannya di $S D / M I / S M P / M T S / M M A / S M K$. Yogyakarta: Graha Cendekia. 2014

[2] Hosnan, M. Pendekatan Saintifik dan Kontekstual dalam Pembelajaran. Bogor: Ghalia Indonesia.2014

[3] Prastowo, A. Pengembangan Bahan Ajar Tematik. Yogyakarta: Diva Press. 2013

[4] Sa'ud, U. S. Inovasi Pendidikan. Bandung: Alfabeta. 2013

\section{DOKUMENTASI KEGIATAN}

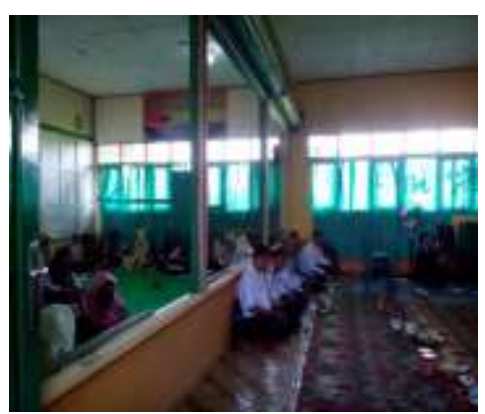

Gambar i. Penyampaian materi pelatihan

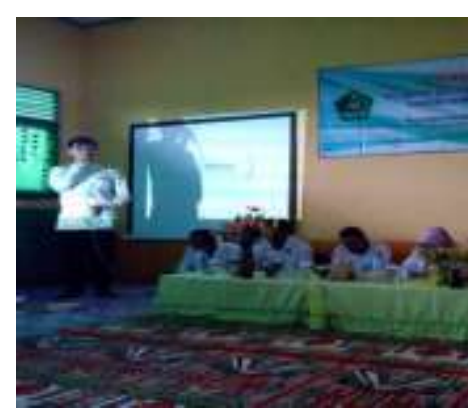

Gambar ii. Pesta kegiatan 